\title{
Pancreatic STAT3 Protects Mice against Caerulein- Induced Pancreatitis via PAP1 Induction
}

\author{
Minoru Shigekawa, ${ }^{*}$ Hayato Hikita, ${ }^{*}$ \\ Takahiro Kodama, ${ }^{*}$ Satoshi Shimizu, ${ }^{*}$ Wei Li, ${ }^{*}$ \\ Akio Uemura, ${ }^{*}$ Takuya Miyagi, ${ }^{*}$ Atsushi Hosui, ${ }^{*}$ \\ Tatsuya Kanto, ${ }^{*}$ Naoki Hiramatsu, ${ }^{*}$ \\ Tomohide Tatsumi, ${ }^{*}$ Kiyoshi Takeda, ${ }^{\dagger}$ \\ Shizuo Akira, ${ }^{\star}$ and Tetsuo Takehara* \\ From the Department of Gastroenterology and Hepatology* and the \\ Laboratory of Immune Regulation, ${ }^{\dagger}$ Department of Microbiology and \\ Immunology, Osaka University Graduated School of Medicine, Suita; \\ and the Laboratory of Host Defense, ${ }^{\ddagger}$ World Premier International \\ Immunology Frontier Research Center, Suita, Japan
}

The signal transducer and activator of transcription 3 (STAT3) is a transcription factor that controls expressions of several genes involved in cell survival, proliferation and differentiation, and tissue inflammation. However, the significance of pancreatic STAT3 in acute pancreatitis remains unclear. We generated conditional STAT3 knockout (stat $3^{\Delta / \Delta}$ ) mice by crossing stat $3^{\text {flox/flox }}$ mice with Pdx1-promoter Cre transgenic mice. Caerulein administration activated pancreatic STAT3 and induced acute pancreatitis as early as 3 hours in wild-type mice, and full recovery from the induced pancreatic injury was observed within 7 days. The levels of serum amylase and lipase and histologic scores of pancreatic necrosis and inflammatory cell infiltration were significantly higher at 3 hours in $s t a t 3^{\Delta / \Delta}$ mice than in stat $3^{\text {flox/flox }}$ mice. Pancreatic recovery after pancreatitis was significantly delayed in $s t a t 3^{\Delta / \Delta}$ mice compared with stat $3^{\text {flox/flox }}$ mice. Although stat $3^{\text {flox/flox }}$ mice had marked production in the pancreas of pancreatitis-associated protein 1 (PAP1), a serum acute phase protein, this induction was completely abrogated in $\operatorname{stat}^{\Delta / \Delta}$ mice. Enforced production of PAP1 by a hydrodynamic procedure in the liver significantly suppressed pancreatic necrosis and inflammation and also promoted pancreatic regeneration and recovery in $\operatorname{stat}^{\Delta / \Delta}$ mice to levels similar to those observed in stat $3^{\text {fox } / \text { /lox }}$ mice. In conclusion, pancreatic STAT3 is indispensable for PAP1 production, and this STAT3/PAP1 pathway plays a protective role in caerulein-induced pancreatitis. (Am J Pathol 2012, 181:2105-2113; http://dx. doi.org/10.1016/j.ajpath.2012.08.038)
Acute pancreatitis is a common digestive disease characterized by edema, necrosis, hemorrhage, and severe inflammatory cell infiltration of the pancreas. ${ }^{1}$ Its onset is triggered by acinar events, involving premature intra-acinar activation of digestive zymogens that induce autodigestion and acinar cell injury. ${ }^{2}$ Previous studies have reported that cytokines, especially proinflammatory cytokines, such as tumor necrosis factor (TNF)- $\alpha$, IL-1 $\beta$ and IL-6, and chemokines [eg, monocyte chemoattractant protein-1 (MCP-1)] derived from stimulated acinar cells, play a key role in the disease pathology of acute pancreatitis. ${ }^{3}$ Acinar cell destruction also results in activation and infiltration of inflammatory cells, which release proinflammatory mediators, such as the cytokines and reactive oxygen species. ${ }^{4}$ Excessive production of cytokines leads to a systemic inflammatory response and multiple organ failure, ${ }^{5}$ as evidenced by the fact that levels of circulating inflammatory cytokines, including IL-6, are correlated with disease severity in human pancreatitis. ${ }^{6-8}$ Acute pancreatitis remains a difficult clinical problem, causing severe motility and morbidity. Thus, the cellular mechanisms underlying the pathogenesis of acute pancreatitis need to be elucidated.

The signal transducers and activators of the transcription (STAT) family are transcription factors that are associated with mediating inflammatory responses. The STAT signaling pathway is activated by a diverse array of cytokines and growth factors and has been implicated in a variety of biological events, such as proliferation, cell survival, and immune response. ${ }^{9}$ Among the STAT family, STAT3 was formerly known as an acute-phase response factor, which regulates the expression of genes involved in a series of inflammatory reactions induced in response to infection and tissue injury..$^{10}$ Proinflammatory cytokine IL- $6^{11}$ or lipopolysaccharides ${ }^{12}$ have been shown to activate this factor. Previous reports indicate that STAT3 protects cardiomyocytes against apoptosis during myocardiac injury ${ }^{13}$ and promotes proliferation in hepatocytes after partial hepatectomy. ${ }^{14}$ In

Supported by a Grant-in-Aid for Scientific Research from the Ministry of Education, Culture, Sports, Science, and Technology, Japan.

Accepted for publication August 28, 2012.

Supplemental material for this article can be found at http://ajp. amjpathol.org or at $h$ ttp://dx.doi.org/10.1016/j.ajpath.2012.08.038.

Address reprint requests to Tetsuo Takehara, M.D., Ph.D., 2-2 Yamada-oka, Suita, Osaka 565-0871, Japan. E-mail: takehara@gh.med.osaka-u.ac.jp. 
addition, we have previously demonstrated that the soluble factors dependent on hepatic STAT3, such as acute-phase proteins, suppress innate immune cell overactivation and hypercytokinemia to aid host defense during systemic inflammation. ${ }^{15}$ Recent studies have found that STAT3 in acinar cells could be activated by several inflammatory mediators, such as TNF- $\alpha$ or lipopolysaccharide. ${ }^{16,17}$ In addition, STAT3 activated by oxidative stress was found to induce MCP-1 expression in acinar cells. ${ }^{18}$ Although this transcription factor may be involved in pancreatic injury during acute inflammation, the pathologic and physiologic mechanisms of pancreatitis in relation to the pancreatic STAT3 pathway remain unclear.

In the present study, we examined the effects of the pancreatic STAT3 signaling pathway on acute pancreatitis. Because systemic deletion of STAT3 leads to embryonic lethality in mice, ${ }^{19}$ we used conditional knockout mice with deletion of pancreatic STAT3 using the Cre/ loxP system. We found that its signaling pathway offered protection from acinar cell death and inflammatory cell infiltration during caerulein-induced pancreatitis. Moreover, the expression of pancreatitis-associated protein 1 (PAP1) from the pancreas, which is known as an acutephase response factor in inflammation, was completely dependent on pancreatic STAT3 and was involved in attenuation of the severity of pancreatitis in mice with deletion of pancreatic STAT3. Thus, we concluded that pancreatic STAT3 plays a protective role in modulating pancreatic injury and inflammatory infiltration during caerulein-induced pancreatitis via PAP1 production.

\section{Materials and Methods}

\section{Animals}

Mice carrying a STAT3 gene with 2 loxP sequences flanking exon 22 (stat3 $3^{\text {flox } f l o x}$ ) have been described previously. ${ }^{20}$ Conditional STAT3 knockout $\left(\right.$ stat3 ${ }^{\Delta \Delta}$ ) mice were generated by crossing stat $3^{\text {floxflox }}$ mice with $p d x 1$-Cre transgenic mice to obtain deletion of STAT3 within the pancreas. Sexmatched stat3flox/flox mice obtained from the same litter were used as wild-type (WT) controls. All animals were used at the age of 7 to 10 weeks and housed with 12-hour light/dark cycles with free access to food and water under specific pathogen-free conditions. Mice were treated with humane care under approval from the Animal Care and Use Committee of Osaka University Medical School.

\section{Animal Model of Acute Pancreatitis}

Acute pancreatitis was induced by eight hourly i.p. injections of $50 \mu \mathrm{g} / \mathrm{kg}$ of caerulein (Sigma-Aldrich, St. Louis, MO) for 2 consecutive days, whereas the controls were administered PBS in the same way. For caerulein-induced pancreatitis, stat $3^{\Delta \Delta}$ and stat3 fox fllox mice were fasted for 12 hours before the treatment but provided with water ad libitum.

\section{Preparation of Tissue and Serum Samples}

Tissues from the pancreas were removed, weighed, immediately frozen in liquid nitrogen, and stored at $-80^{\circ} \mathrm{C}$.
Myeloperoxidase activity in the pancreas samples was measured using a Myeloperoxidase Detection Kit according to the manufacturer's protocol (Cell Technology Inc., Mountain View, CA). Whole blood samples were centrifuged at $15,000 \times g$ for 20 minutes at $20^{\circ} \mathrm{C}$, and serum was used for biochemical examinations of amylase and lipase with commercially available assays ( $\mathrm{Na}$ gahama Life Science Laboratory, Nagahama, Japan).

\section{Histologic Analysis}

Formalin-fixed pancreatic tissue sections were stained with $\mathrm{H} \& \mathrm{E}$ to assess pancreatic necrosis and inflammatory cell infiltration. Necrotic cells were defined as ones that were swollen, had lost plasma membrane integrity, and had leakage of cytoplasm into the interstitium. The extent of the necrotic area was scored using the following scale: 0 , none; $1,<30 \%$;, $30 \%$ to $70 \%$; and 3, $>70 \%$. Quantification of the necrotic area (necrotic area score) was the sum of the scales obtained in four high-powered fields of pancreatic tissue sections with H\&E on a range of 0 to 12 . In a similar way, the intensity of inflammatory infiltration (inflammatory infiltration score) was scored in four fields, using the following 1- to 3-point scale (resulting in a score of 0 to 12) for the extension of inflammatory cell infiltration: 0, none; 1 , surrounding pancreas; 2, intralobular area; and 3, surrounding acini. To detect apoptotic cells, the pancreatic tissue sections were also subjected to TUNEL staining as previously reported. ${ }^{21}$ To assess proliferative cells in the injured pancreas, pancreatic sections were stained using an anti-Ki-67 antibody (Abcam, Cambridge, MA).

\section{Western Blot Analysis}

Approximately $25 \mathrm{mg}$ of pancreatic tissues was lysed with a lysis buffer [ $1 \% \mathrm{NP}-40,0.5 \%$ sodium deoxycholate, $0.1 \%$ sodium dodecyl sulfate, $1 \times$ protease inhibitor cocktail (Nacalai Tesque, Kyoto, Japan), $1 \times$ phosphatase inhibitor cocktail (Nacalai Tesque), and phosphate-buffered saline ( $\mathrm{pH}$ 7.4)]. After incubation on ice for $20 \mathrm{~min}$ utes, the lysate was centrifuged at $10,000 \times g$ for 20 minutes at $4^{\circ} \mathrm{C}$. The protein content of the supernatant was determined using a bicinchoninic acid protein assay kit (Pierce, Rockford, IL). Equal amounts of protein were electrophoretically separated by SDS-PAGE and transferred onto polyvinylidene fluoride membrane. For immunodetection, the following antibodies were used: antiphospho-STAT3 (Tyr705) antibody, anti-STAT3 antibody (Cell Signaling Technology, Danvers, MA), anti-Bcl-xL antibody (Santa Cruz Biotechnology Inc, Delaware, CA), anti-Mcl-1 antibody (Rockland, Gillbertsville, PA), anti- $\beta$ actin antibody (Sigma-Aldrich), and anti-mouse ReglllB (PAP1) antibody (R\&D Systems, Minneapolis, MN).

\section{Real-Time RT-PCR}

Total RNA was extracted from the pancreatic tissue using an RNeasy kit (QIAGEN, Tokyo, Japan). For complementary DNA synthesis, $1 \mu \mathrm{g}$ of total RNA was reverse transcribed using the High Capacity RNA-to-DNA Master Mix 
(Applied Biosystems Inc, Foster City, CA) and subjected to real-time RT-PCR. The mRNA expression of specific genes was measured using Taqman Gene Expression Assays (Applied Biosystems Inc). Assay IDs of the respective genes are Cd68: Mm03047343_m1, il6: Mm01210733_m1, and Cc/2: Mm00441242_m1.The levels of gene expression were corrected with the quantified expression level of glyceraldehyde 3-phosphate dehydrogenase (Gapdh: Mm99999915_g1) mRNA.

\section{Enzyme-Linked Immunosorbent Assay}

The levels of IL-6 in serum were measured using Quantikine Mouse IL-6 Immunoassay (R\&D Systems) according to the manufacturer's protocol.

\section{Injection of Naked Plasmid DNA}

A plasmid containing the murine full-length Reg3A (human alias, PAP1) gene (pCMV-PAP1; C-terminal Myc and DDK tagged) was purchased from Origene Technologies Inc (Rockville, MD). The plasmid itself served as a control $(\mathrm{pCMV})$. The plasmid DNA was prepared using an EndoFree plasmid system (QIAGEN) according to the manufacturer's instructions. Hydrodynamic injection of plasmid DNA was performed as previously described..$^{22}$ In brief, $50 \mu \mathrm{g}$ of plasmid DNA was diluted with $2.0 \mathrm{~mL}$ of lactated Ringer's solution and injected into the tail vein, using a syringe with a 26-gauge needle. DNA injection was completed within 5 to 8 seconds.

\section{Statistical Analysis}

Data are presented as the mean \pm SD. Differences between groups were compared using the unpaired $t$-test. The level of statistical significance was set at $P<0.05$.

\section{Results}

\section{Pancreatic STAT3 Is Activated in the Early Phase of Pancreatitis}

Acute pancreatitis was induced by repetitive i.p. injections of caerulein, an analog of the secretagogue cholecystokinin, to WT mice, and activation of STAT3 was observed in the pancreas. Western blot analysis clearly revealed phosphorylation of STAT3 in the pancreas at 3 , 24, and 72 hours after the last injection of caerulein; expression was strongest at 3 hours and decreased over time (Figure 1A). WT mice given caerulein treatment had a significant increase in serum levels of amylase at 3 hours but not at later time points (Figure 1B). Histologic findings at 3 hours revealed typical morphologic changes characterized by edema, vacuolization, inflammatory cell infiltration, and acinar cell death, which were gradually improved at later time points (Figure 1C). We evaluated
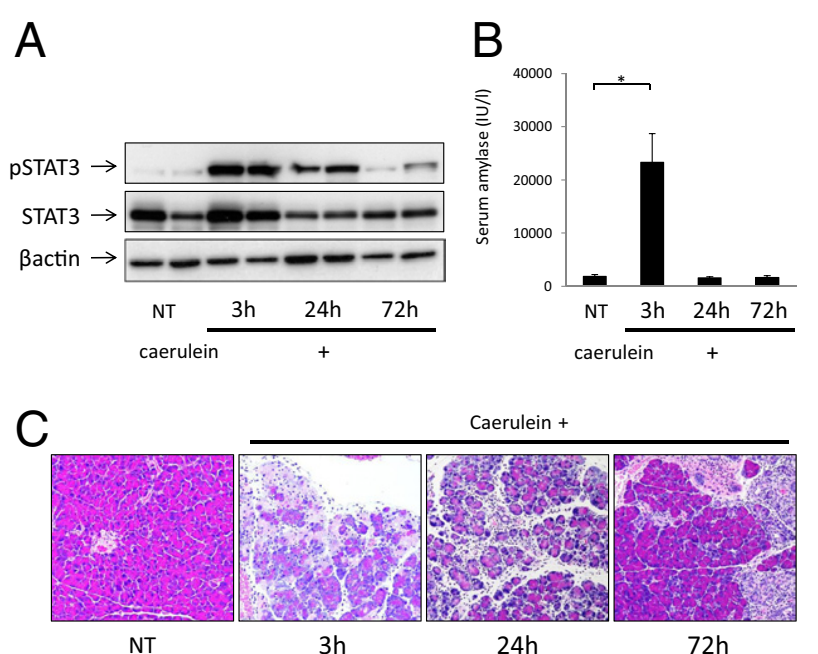

Figure 1. Activation of pancreatic STAT3 in caerulein-induced pancreatitis. WT mice were subjected to eight hourly i.p. injections of caerulein $(50 \mu \mathrm{g} / \mathrm{kg})$ for 2 consecutive days. The mice were sacrificed at 3,24, or 72 hours after the last injection ( $n=8$ per group). The mice without caerulein treatment (NT) served as controls. A: Expressions of STAT3 and phosphorylated STAT3 (pSTAT3) in the pancreas were assessed by Western blot analysis. $\beta$-Actin was included as a control. B: Pancreatic injury was determined by measuring serum levels of amylase. ${ }^{*} P<0.05$. C: Representative views of H\&E staining of the pancreatic sections. Original magnification, $\times 200$.

the function of pancreatic STAT3 during caerulein-induced pancreatitis, mainly 3 hours after the last injection.

\section{Ablation of Pancreatic STAT3 Exacerbates Caerulein-Induced Pancreatitis}

Conditional STAT3 knockout mice were generated by crossing floxed STAT3 mice and pdx1-Cre transgenic mice. $P d x 1$ is known to be expressed in the developing pancreas, stomach, and duodenum of mice. ${ }^{23}$ stat $^{\text {flox flox }}$ pdx1-Cre (ie, stat $3^{\Delta / \Delta}$ ) mice were born with the expected mendelian characteristics. No significant difference was found between body weight and serum levels of amylase and lipase between stat $3^{\Delta / \Delta}$ mice and stat $3^{\text {flox fllox }}$ mice at the age of 8 weeks (see Supplemental Figure S1, A and $\mathrm{B}$, at http://ajp.amjpathol.org). The relative weight and histology of the pancreas also showed no difference between them (see Supplemental Figure S1, C and D, at http://ajp.amjpathol.org). As expected, stat3 ${ }^{\Delta / \Delta}$ pancreas expressed substantially lower levels of STAT3 than stat3 $^{\text {flox/flox }}$ pancreas (Figure 2A). To clarify the significance of pancreatic STAT3 during acute pancreatitis, we examined the severities of caerulein-induced pancreatitis in $\operatorname{stat}^{\Delta / \Delta}$ and stat $^{\text {flox }}{ }^{\text {flox }}$ mice. In stat3 ${ }^{\Delta / \Delta}$ mice with caerulein treatment, serum levels of amylase and lipase were significantly higher than in stat $^{\text {flox }}{ }^{\text {fflox }}$ mice at 3 hours after the last injection (Figure 2B). Histologic examination of $\operatorname{stat}^{\Delta / \Delta}$ pancreas revealed marked exacerbation of necrotic cell death and inflammatory cell infiltration compared with stat3 $3^{\text {flox/flox }}$ pancreas (Figure 2C). To detect apoptotic cells, the pancreatic sections were subjected to TUNEL staining. The number of TUNEL-positive cells was significantly higher at 3 hours after the last injection in stat $3^{\Delta / \Delta}$ pancreas than 
A
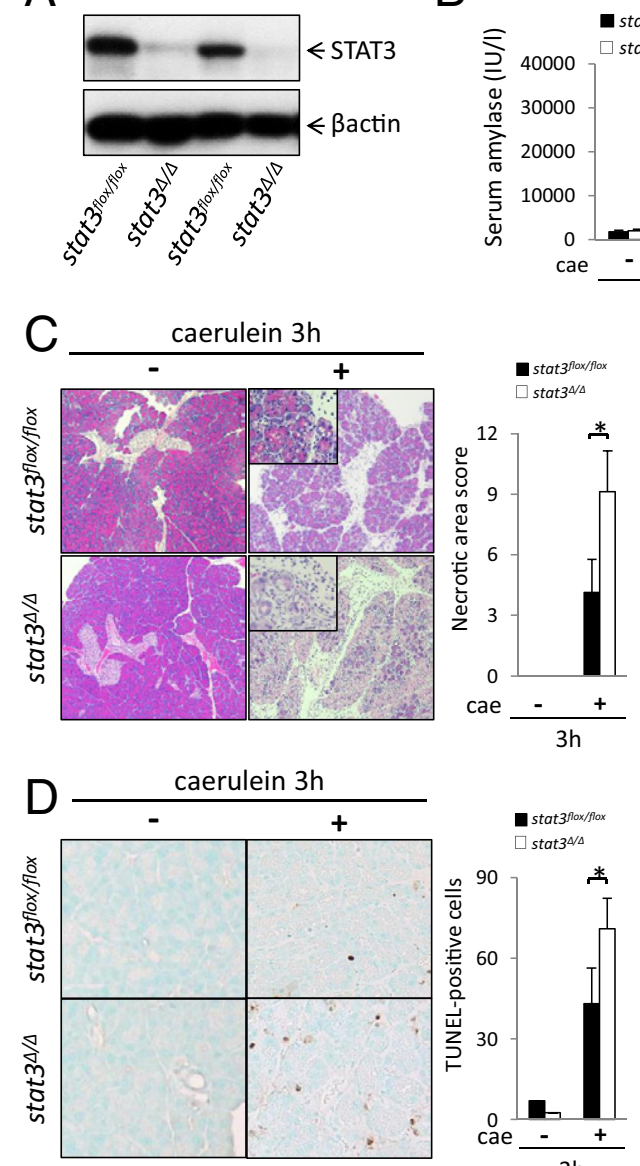

B



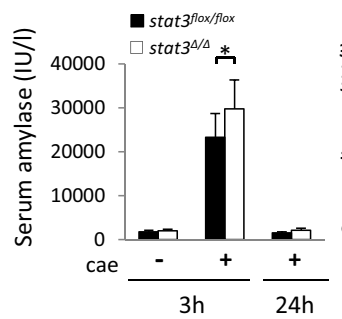
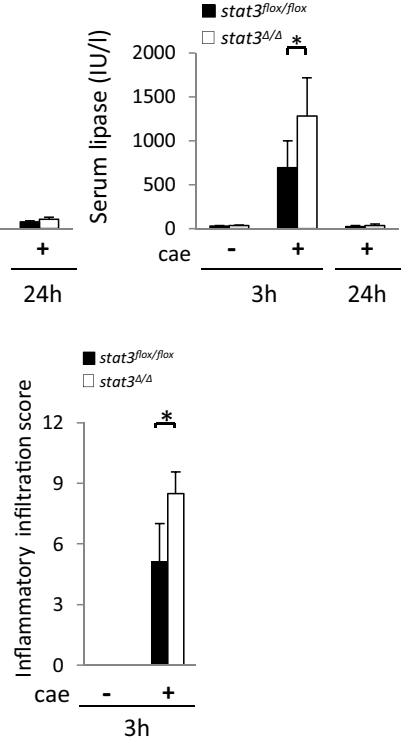

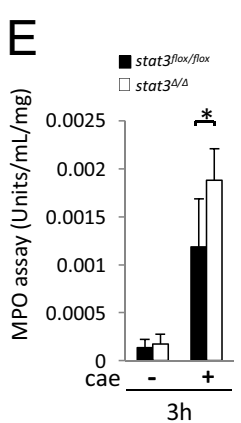

$\mathrm{F}$
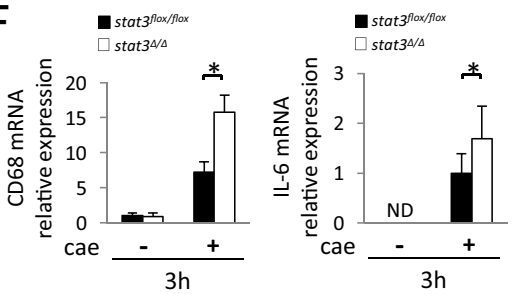

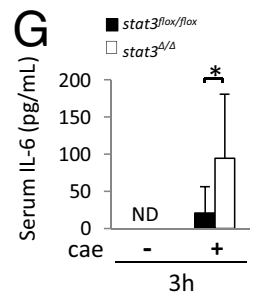

Figure 2. STAT3 knockdown in the pancreas in creases caerulein-induced pancreatic injury. Acute pancreatitis was induced in $s t a t 3^{\Delta / \Delta}$ and stat $3^{\text {flox } f l o x}$ mice by eight hourly i.p. injections of caerulein $(\mathrm{cae}+)$ or vehicle $(\mathrm{cae}-)$ for 2 consecutive days. The mice were sacrificed at 3 or 24 hours after the last injection of caerulein. stat $3^{\Delta / \Delta}$ stands for stat $3^{\text {flox/flox }}$ pdx1-Cre. A: Expression of STAT3 in the pancreas of $\operatorname{stat}^{\Delta / \Delta}$ and stat $3^{\text {flox/flox }}$ mice before the treatment by Western blot analysis. B Pancreatic injury was determined by measuring serum levels of amylase and lipase $(n=8$ per group). C: Representative views of H\&E staining of the pancreatic sections at 3 hours after the las injection of caerulein. Necrotic area score and inflammatory infiltration score were quantified on H\&E-stained pancreatic sections ( $n=6$ to 8 per group). D: Representative views of TUNEL staining of the pancreatic sections at 3 hours after the last injection of caerulein and statistics of TUNEL-positive cells per six high-powered fields ( $n=8$ per group). E: Pancreatic myeloperoxidase activity was measured in the pancreas ( $n=6$ to 8 per group). F: Expression of CD68, IL-6, and MCP-1 mRNAs in the pancreas was assessed by real-time RT-PCR analysis ( $n=6$ to 8 per group). G: Expression of IL-6 in serum was assessed by enzymelinked immunosorbent assay ( $n=6$ to 8 per group). ${ }^{*} P<0.05$. ND, not detected. Original magnification: $\times 200$ (Cand D); $\times 400$ (inset in C). in stat3 ${ }^{\text {flox/flox }}$ pancreas (Figure 2D). stat3 ${ }^{\Delta / \Delta}$ mice with caerulein treatment had significantly increased levels of myeloperoxidase activity, which represented the levels of polymorphonuclear leukocyte infiltration, and mRNA expression of CD68, which is a marker of macrophages (Figure 2, $\mathrm{E}$ and $\mathrm{F}$ ). In stat $3^{\Delta / \Delta}$ mice, mRNA expressions of inflammatory mediators, such as IL-6 and MCP-1 in the pancreas and IL-6 levels in circulation, significantly increased compared with stat $3^{\text {flox/flox }}$ mice (Figure 2, F and G).

\section{Pancreatic Recovery Is Delayed in stat $3^{\Delta / \Delta}$ Mice during Caerulein-Induced Pancreatitis}

Caerulein-induced epithelial injury is recognized as a fully reversible process. ${ }^{24}$ To assess the regeneration process in our model, we examined the relative pancreatic weight and histologic features in $\operatorname{stat}^{\Delta / \Delta}$ and stat ${ }^{\text {flox/flox }}$ mice during caerulein-induced pancreatitis over time. In stat3 ${ }^{\text {flox/flox }}$ mice, histologic examination revealed that injured acinar cells were almost fully restored at 7 days after caerulein administration (Figure 3A). In agreement with this, relative pancreatic weight, which decreased after caerulein administration, recovered to the baseline levels at this time point (Figure 3B). The number of cells positive for $\mathrm{Ki}-67$ protein, a cellular marker for proliferation, revealed the greatest increase at 3 days in stat ${ }^{\text {flox/flox }}$ pancreas and gradually decreased over time (Figure 3, C and D). On the other hand, stat $3^{\Delta / \Delta}$ mice had histologic exacerbation of the pancreas compared with stat ${ }^{\text {flox/flox }}$ mice after caerulein administration (Figure $3 \mathrm{~A}$ ). The relative pancreatic weight of $\operatorname{stat}^{\Delta / \Delta}$ mice was significantly lower at 3, 5, and 7 days than that of stat3 flox/flox mice and finally recovered to the baseline levels at 14 days (Figure 3B). In addition, we observed a peak delay of the number of 
A

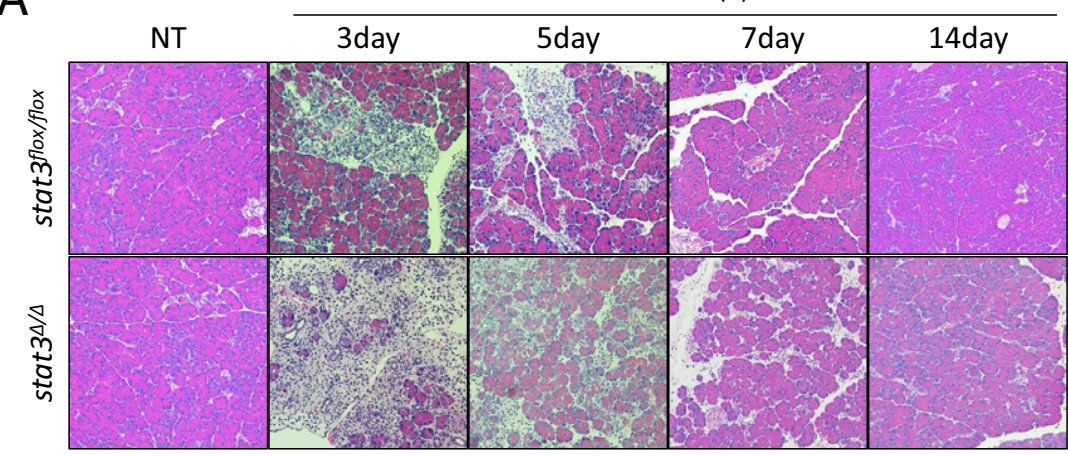

C

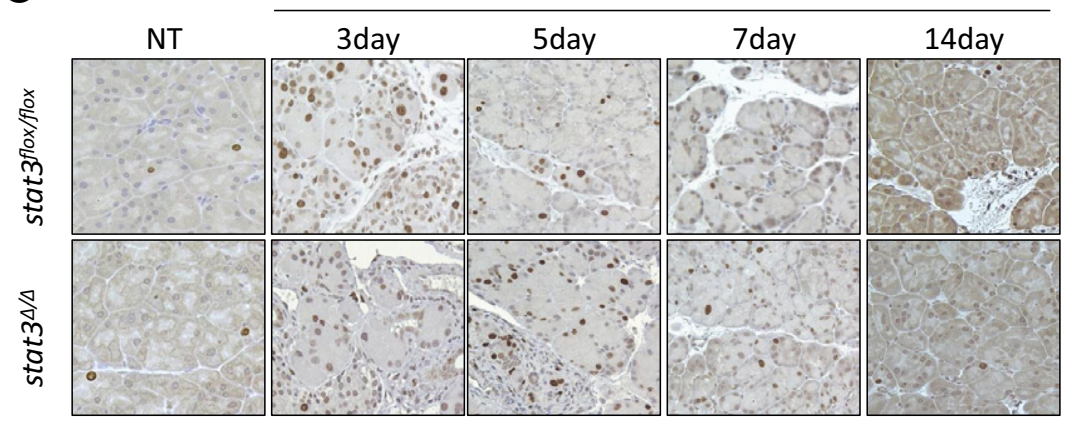

B

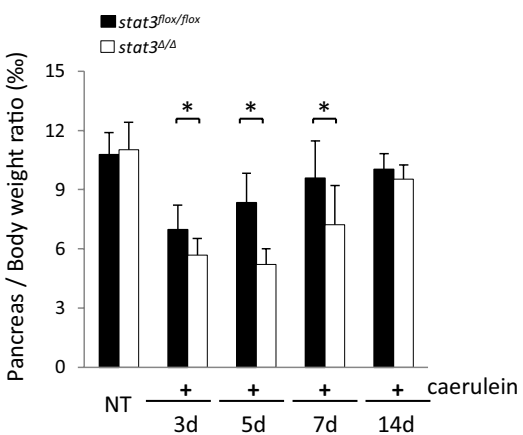

D

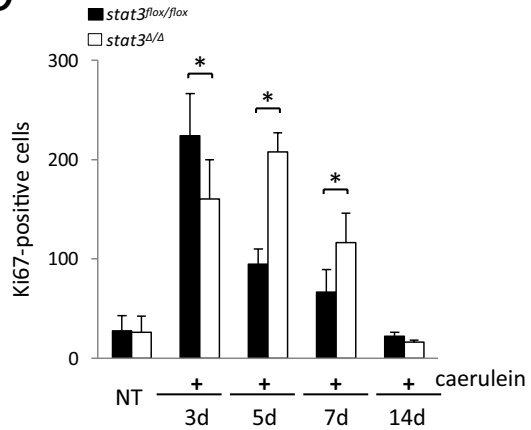

Figure 3. Delayed restoration of the injured pancreas in $s t a t 3^{\Delta / \Delta}$ mice during caerulein-induced pancreatitis. Acute pancreatitis was induced in stat $3^{\Delta / \Delta}$ and

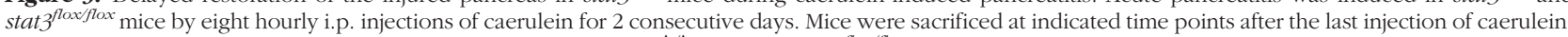
The mice without caerulein treatment (NT) served as controls. stat $3^{\Delta / \Delta}$ stands for stat $3^{\text {floxfflox }}$ pdx 1 -Cre. A: Representative views of H\&E staining of the pancreatic sections in $s t a t 3^{\Delta / \Delta}$ and stat $3^{\text {flox } f l o x}$ mice. B: Relative pancreatic weight in stat $^{\Delta / \Delta}$ and stat ${ }^{\text {flox } f l o x}$ mice $(n=7$ per group). C: Representative views of Ki-67 immunohistochemical staining of the pancreatic sections. D: Statistics of Ki-67-positive cells per four high-powered fields $\left(n=4\right.$ to 8 per group). ${ }^{*} P<0.05$. Original magnification: $\times 200(\mathbf{A}$ and $\mathbf{C})$.

Ki-67 positive cells in the pancreas of stat $^{\Delta / \Delta}$ mice (Figure 3, C and D). A loss of pancreatic STAT3 led to delayed restoration of the injured pancreas during caerulein-induced pancreatitis.

\section{PAP1 Is Not Induced in the Pancreas of stat $3^{\Delta / \Delta}$ Mice by Caerulein Treatment}

PAP1 was first discovered in the pancreas of rats with acute pancreatitis. ${ }^{25}$ This protein was absent in control rats but appeared early after induction of pancreatitis and remained in an overexpressed state during inflammation. It is considered to be one of the acute-phase proteins. Serum levels of PAP1 have been reported to increase in patients with acute pancreatitis and to decrease steadily during recovery. ${ }^{26}$ The expression of this secretory protein can be induced by several inflammatory cytokines and by itself through a JAK/ STAT3-dependent pathway. ${ }^{27}$ At least two functional STAT3-responsible elements have been reported in the promoter of gene encoding PAP1, so a regulatory link between PAP1 and STAT3 has been proposed. ${ }^{28}$ We examined PAP1 expression during caerulein-induced pancreatitis. In stat3 $3^{\text {floxflox }}$ mice, PAP1 was markedly induced by caerulein treatment in the injured pancreas at 3 hours after the last injection but not in the liver and the lung (Figure 4A). In sharp contrast, it was not observed in the pancreas of $\operatorname{stat}^{\Delta / \Delta}$ mice with caerulein treatment (Figure 4B). PAP1 was secreted in a STAT3-dependent manner from the injured pancreas during caerulein-induced pancreatitis.
A

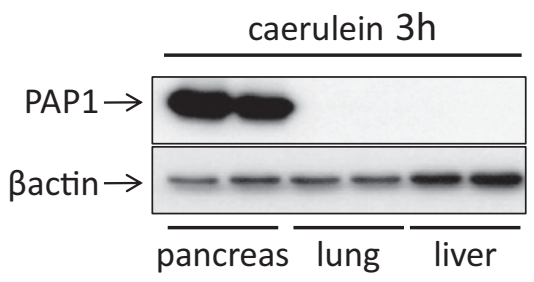

B $3 h$

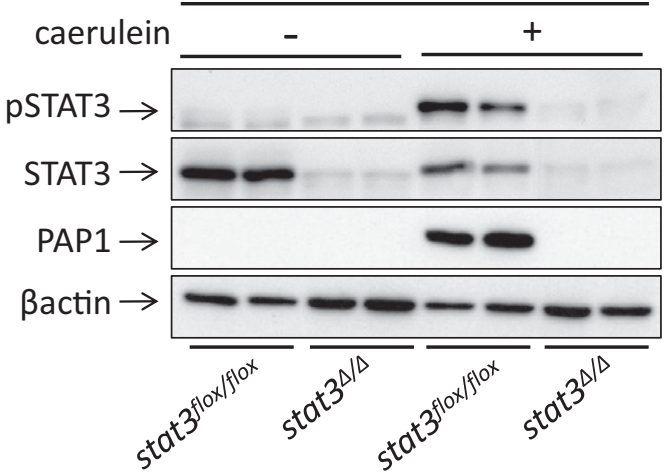

Figure 4. Induction of PAP1 is impaired during pancreatitis in stat $3^{\Delta / \Delta}$ mice. Acute pancreatitis was induced in $s t a t 3^{\Delta / \Delta}$ and stat $3^{\text {flox/flox }}$ mice by eight hourly i.p. injections of caerulein for 2 consecutive days. The mice were sacrificed 3 hours after the last injection of caerulein. stat $3^{\Delta / \Delta}$ stands for stat $3^{\text {flox/flox }}$ pdx1-Cre. A: Expressions of PAP1 in caerulein-treated pancreas, lung, and liver of stat3 flox/flox mice by Western blot analysis. $\beta$-Actin was included as a control. B: Expressions of STAT3, pSTAT3, and PAP1 in the pancreas were assessed by Western blot analysis. $\beta$-Actin was included as a control. 
A



$\mathrm{B}$

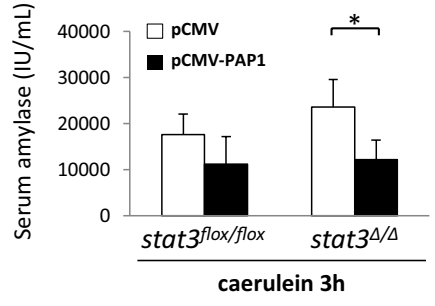

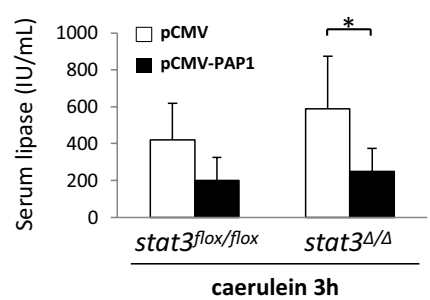

C



caerulein $3 \mathrm{~h}$

$\mathrm{D}$
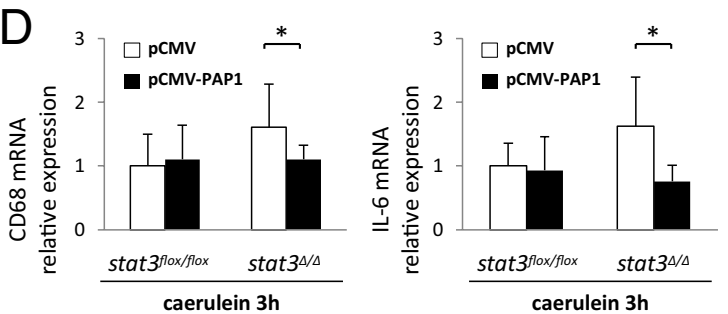

Enforced Expression of Gene Encoding PAP1 in the Liver Attenuates the Severity of CaeruleinInduced Pancreatitis and Promotes Pancreatic Recovery in stat $3^{\Delta / \Delta}$ Mice

To examine whether PAP1 deficiency in stat3 ${ }^{\Delta / \Delta}$ mice could be ascribed to exacerbation of caerulein-induced pancreatitis, enforced PAP1 expression was induced in the liver by a hydrodynamic injection procedure. Mice received PCMV-PAP1 or PCMV and after 36 hours were subjected to 2 days of caerulein treatment. PAP1 was clearly produced in the liver at 36 hours after hydrodynamic injection (Figure 5A). Both stat $3^{\Delta / \Delta}$ and stat3 flox/flox mice treated with pCMV exhibited typical features of pancreatitis at 3 hours after the last caerulein injection (Figure $5, B$ and $C$ ). Of importance is the finding that the serum levels of amylase and lipase in stat $3^{\Delta / \Delta}$ mice injected with PCMV-PAP1 were significantly lower than those in stat $^{\Delta / \Delta}$ mice injected with pCMV (Figure 5B). The extent of the necrotic area and the degree of inflammatory cell infiltration were significantly lower in stat $3^{\Delta / \Delta}$ mice treated with PCMV-PAP1 than those with PCMV injection (Figure $5 C)$. Moreover, stat ${ }^{\Delta / \Delta}$ mice treated with pCMV-PAP1 had a marked decrease of the mRNA expressions of CD68 and IL-6 in the injured pancreas compared with those treated with pCMV (Figure 5D). In contrast, the number of TUNEL-positive cells did not differ in stat3 ${ }^{\Delta / \Delta}$

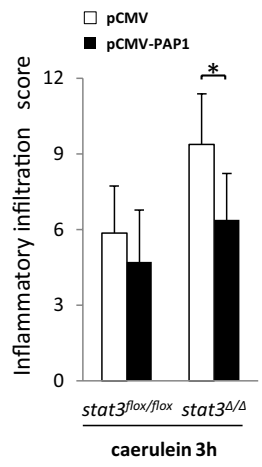

Figure 5. Enforced expression of gene encoding PAP1 in the liver attenuated the severity of caerulein-induced pancreatitis in $\operatorname{stat}^{\Delta / \Delta}$ mice. $\operatorname{stat}^{\Delta / \Delta}$ and stat $3^{f l o x}$ flox mice injected with the plasmid containing pCMV-PAP1 or PCMV via the tail vein by a hydrodynamic injection procedure and after 36 hours were subjected to eight hourly i.p. injections of caerulein for 2 consecutive days. Mice were sacrificed at 3 hours after the last caerulein injection ( $n=7$ per group). A: Expressions of PAP1 in the liver of $\operatorname{stat}^{\Delta / \Delta}$ and stat $3^{\text {flox flox }}$ mice at 36 hours after hydrodynamic injection by Western blot analysis. $\beta$-Actin was included as a control. B: Pancreatic injury was determined by measuring serum levels of amylase and lipase. C: Representative views of the H\&E-stained pancreatic sections of $\operatorname{stat}^{\Delta / \Delta}$ and stat $3^{\text {flox } f l o x}$ mice treated with pCMV-PAP1 or pCMV and statistics of necrotic area score and inflammatory infiltration score. D: Expression of CD68 and IL-6 mRNA was assessed by real-time RT-PCR analysis. E: The number of TUNEL-positive cells per six high-powered fields. ${ }^{*} P<0.05$. Original magnification: $\times 200$ (C).

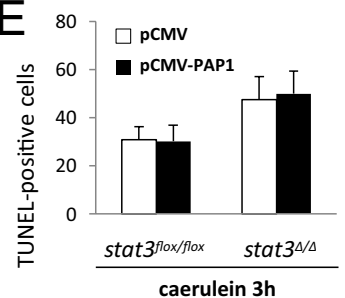

mice between the PCMV-PAP1 injection and PCMV injection groups (Figure 5E; see also Supplemental Figure S2A at $h$ ttp://ajp.amjpathol.org). We also examined the pancreatic recovery in $s t a t 3^{\Delta / \Delta}$ mice pretreated with PCMV-PAP1 or pCMV at 3 days after the last caerulein injection. The PAP1-treated group had clear improvement of pancreas histologic findings (Figure 6A). The relative pancreatic weight of $s t a t 3^{\Delta / \Delta}$ mice with PAP1 treatment significantly increased compared with those given the control treatment; it did not differ from that of stat $3^{\text {flox/flox }}$ mice (Figure 6B). In addition, the number of Ki-67 positive cells in stat $3^{\Delta / \Delta}$ mice with PAP1 treatment also significantly increased (Figure $6 C$ ). These results suggest that enforced PAP1 expression not only attenuated the severity of the necrotizing pancreatitis with infiltration of inflammatory cells but also promoted pancreatic recovery in $s t a t 3^{\Delta / \Delta}$ mice with caerulein treatment.

\section{Discussion}

The STAT3 pathway is not essential for pancreatic organogenesis ${ }^{29}$ but is required for the process of acinarto-ductal metaplasia, which is observed not only in chronic inflammation but also in the pathogenesis of pancreatic ductal adenocarcinoma. ${ }^{29}$ STAT3, which was found to be activated in human pancreatic ductal adenocarcinoma, ${ }^{30}$ regulates a number of pathways impor- 

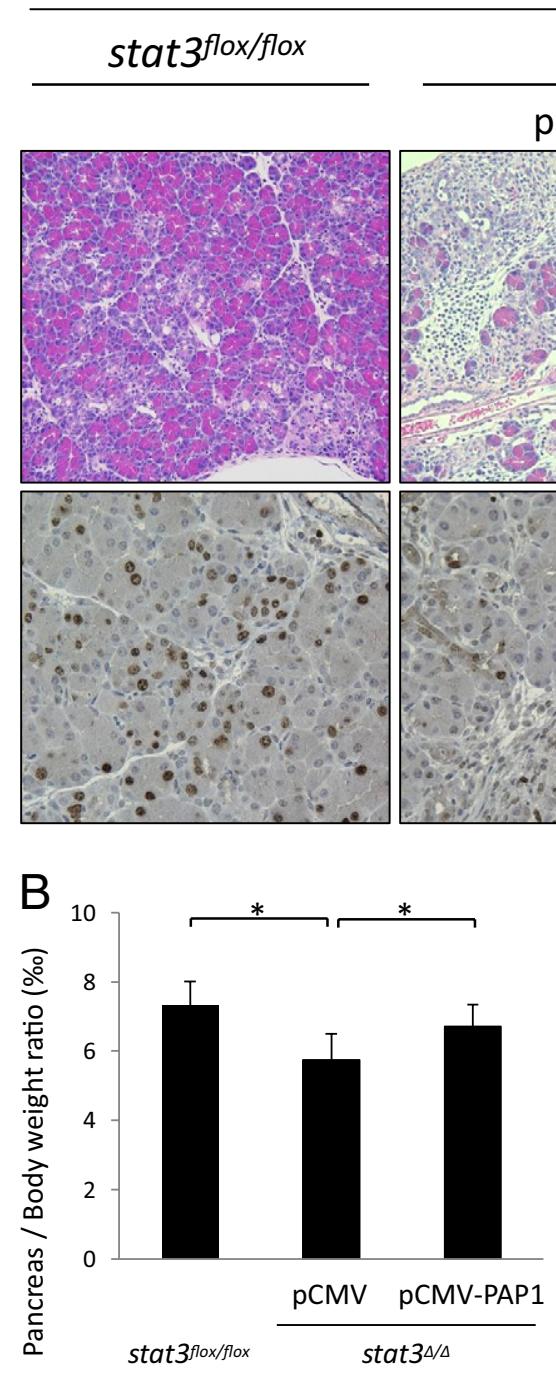

caerulein 3d
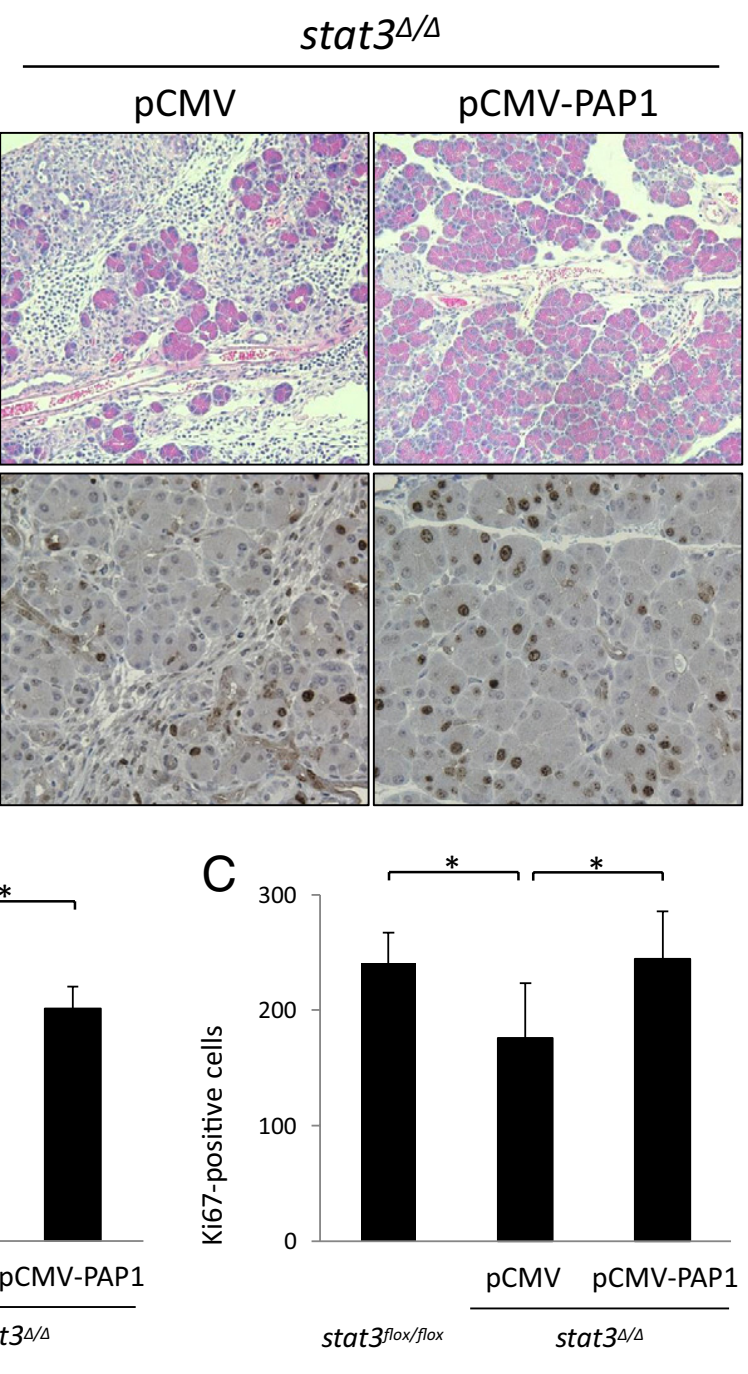

caerulein 3d

Figure 6. Enforced expression of gene encoding PAP1 in the liver promoted pancreas recovery in stat $^{\Delta / \Delta}$ mice during caerulein-induced pancreatitis. At 36 hours before the first caerulein injection, stat $^{\Delta / \Delta}$ mice were injected with pCMV-PAP1 or pCMV via the tail vein by a hydrodynamic injection procedure. Acute pancreatitis was induced in stat $^{\Delta / \Delta}$ and stat $3^{\text {flox flox }}$ mice by eight hourly i.p. injections of caerulein for 2 consecutive days. The mice were sacrificed at 3 days after the last injection of caerulein. A: Representative views of H\&E staining (upper panels) and Ki-67 immunohistochemical staining (lower panels) of the pancreatic sections in stat $3^{\text {flox flox }}$ and stat $^{\Delta / \Delta}$ mice treated with pCMV-PAP1 or pCMV. B: Relative pancreatic weight in stat $3^{\text {flox }}$ flox and $\operatorname{stat}^{\Delta / \Delta}$ mice treated with pCMV-PAP1 or pCMV ( $n=3$ per stat $3^{\text {flox }}$ flox group, $n=6$ per the other groups). C: Statistics of Ki-67 positive cells per four high-powered fields ( $n=3$ per stat $3^{\text {flox/flox }}$ group, $n=6$ per the other groups). ${ }^{*} P<0.05$. Original magnification: $\times 200$ (C); $\times 400(\mathbf{D})$

tant in tumorigenesis, including cell cycle progression, apoptosis, tumor angiogenesis, invasion, and metastasis. ${ }^{30-32}$ Although previous work has suggested the importance of pancreatic STAT3 in carcinogenesis, its role in acute inflammation had not been formally examined. In the present study, we demonstrated that genetic ablation of STAT3 in the pancreas exacerbated the course of caerulein-induced acute pancreatitis. stat3 ${ }^{\Delta / \Delta}$ mice had a clear increase in the number of pancreatic inflammatory cells and the levels of pancreatic and circulating inflammatory cytokines, leading to massive pancreatic necrotic change. Our data demonstrate that pancreatic STAT3 has a protective effect against necrotizing pancreatitis with numerous inflammatory infiltrations in vivo. Moreover, stat $^{\Delta / \Delta}$ mice with caerulein treatment had a marked decrease of PAP1 compared with stat3 flox/flox mice. PAP1 is a secretory protein, and enforced expression of gene encoding PAP1 in the liver of $\operatorname{stat}^{\Delta / \Delta}$ mice significantly improved pancreatic necrosis, inflammatory infiltration, and pancreatic recovery during acute pancreatitis. This is the first report, to our knowledge, to demonstrate that the STAT3/PAP1 pathway plays an important role in protection against caerulein-induced pancreatitis.

Research has shown that PAP1 has anti-inflammatory and antiapoptotic activities $27,33,34$ and may be involved in cellular proliferation. ${ }^{35,36}$ PAP1 was discovered in the pancreatic juice of rats after induction of acute pancreatitis, but expression of this secretory protein is not restricted to pancreatic tissue. PAP1 has been observed in several tissues during injuries, including the intestine of inflammatory bowel diseases ${ }^{37}$ and sensory neurons after peripheral injury. ${ }^{38}$ In the exocrine pancreas, PAP1 is only expressed in response to many pancreatic injuries, such as pancreatitis, hypoxia, and lipopolysaccharide injection, as well as in the transplanted tissue. ${ }^{39-42}$ The absence of PAP1 from the healthy tissues and its strong induction observed during the early phase of the disease suggest that PAP1 could be an acute-phase protein induced on tissue injury. In the present study, although caerulein treatment induced strong expression of PAP1 in 
the pancreas, but not in other organs, PAP1 was not induced in $\operatorname{stat}^{\Delta / \Delta}$ mice. This finding indicates that PAP1 is expressed in a STAT3-dependent manner from the injured pancreas during acute pancreatitis.

Anti-inflammatory activity of PAP1 in the pancreas has been reported in in vitro and in vivo studies. In the AR42J pancreatic acinar cell line, purified PAP1 protein inhibited $\mathrm{NF}-\kappa \mathrm{B}$ activation and production of IL-6 and TNF- $\alpha$ in response to TN-F $\alpha .{ }^{43}$ A recent study found that traditional PAP1 knockout mice, on caerulein treatment, had more inflammatory cell infiltration and proinflammatory cytokine production in the pancreas than WT mice and that administration of recombinant PAP1 repressed the inflammatory responses. ${ }^{44}$ Another group reported that conditional rela/p65 knockout mice had marked decrease of PAP1 production and exacerbated pancreatic necrosis and inflammatory cell infiltration during caerulein-induced pancreatitis. This study also demonstrated that knockdown of gene encoding PAP1 in WT mice led to exacerbated necrotizing pancreatitis with inflammatory cell infiltration and that lentiviral gene transfer of PAP1 CDNA reduced the extent of necrosis and inflammatory responses in the pancreas of rela/p65 knockout mice. ${ }^{45}$ In the present study, stat3 ${ }^{\Delta / \Delta}$ mice had severe inflammatory responses and necrosis during caerulein-induced pancreatitis, which were clearly suppressed by PAP1 treatment. This finding is in agreement with the wellrecognized anti-inflammatory role of PAP1 and suggests a close link between inflammation and necrosis during pancreatitis. Traditional PAP1 knockout mice with caerulein treatment had severer inflammation but less severe necrosis in the pancreas. ${ }^{44}$ These results were inconsistent with ours and the data from another group. ${ }^{45} \mathrm{Al}-$ though the reason for this inconsistency is not clear, it may involve the difference in protocols of caerulein treatment, which could affect the severity of the acute pancreatitis.

Recent studies have demonstrated that overexpression of PAP1 prevented apoptosis induced by oxidative stress or TNF- $\alpha$ stimulation in AR42J cells. ${ }^{46,47}$ In traditional PAP1 knockout mice, the pancreas was sensitive to apoptosis during caerulein-induced pancreatitis, and PAP1 treatment reduced pancreatic apoptosis induced by caerulein injection. ${ }^{44}$ In the present study, stat $3^{\Delta / \Delta}$ mice showed increased apoptosis and necrosis during acute pancreatitis. STAT3 is known to regulate several gene expressions of antiapoptotic proteins, such as $\mathrm{Bcl}-\mathrm{xL}$ and $\mathrm{Mcl}-1 .{ }^{48,49}$ Caerulein treatment induced upregulation of $\mathrm{Bcl}-\mathrm{xL}$ in the pancreas of stat3 $3^{\text {flox/flox }}$ mice, whereas the up-regulation of this protein was impaired in stat3 ${ }^{\Delta / \Delta}$ mice (see Supplemental Figure S2B at $h t t p: / /$ ajp.amjpathol.org). This result indicated that $\mathrm{Bcl}-\mathrm{xL}$ is upregulated during pancreatitis, depending on STAT3, and suggested that impaired $\mathrm{Bcl}-\mathrm{XL}$ induction may be involved in the susceptibility to apoptosis in stat ${ }^{\Delta / \Delta}$ pancreas. Interestingly, PAP1 treatment in stat ${ }^{\Delta / \Delta}$ mice significantly reduced the extent of necrosis but did not affect apoptosis. In agreement with this, Western blotting analysis revealed that impaired expression of $\mathrm{Bcl}-\mathrm{XL}$ in stat $^{\Delta / \Delta}$ mice was still observed even with PAP1 treatment (see Supplemental Figure S2B at http://ajp.amjpathol. org). Although it remains obscure why PAP1 treatment had no effect on apoptosis in our model, the antiapoptotic effect of PAP1 might be dependent on pancreatic STAT3 signaling during pancreatitis.

Pancreatic recovery was delayed in stat $3^{\Delta / \Delta}$ mice during acute pancreatitis, and PAP1 treatment promoted its recovery. Although STAT3 activation has been linked to the regeneration process, ${ }^{14,32}$ PAP1 has been also reported to be associated with tissue regeneration and cellular proliferation in the liver and the intestine. ${ }^{35,36}$ Our data demonstrated that deficiency of STAT3 caused severe pancreatic injury early in pancreatitis. This drastic damage of pancreas may lead to the delayed recovery in stat3 ${ }^{\Delta / \Delta}$ mice during caerulein-induced pancreatitis, although the involvement of pancreatic STAT3 or PAP1 in the regeneration phase of the injured pancreas remains obscure in our model. The contribution of pancreatic STAT3 or PAP1 in regeneration needs to be elucidated in further studies using other models of pancreatic regeneration, such as partial pancreatectomy.

In conclusion, our data demonstrate that pancreatic STAT3 is indispensable for inducing PAP1 production in the injured pancreas during acute pancreatitis and that activation of pancreatic STAT3 leads to protective effects against pancreatic injury and inflammation via PAP1 production.

\section{References}

1. Raraty MG, Murphy JA, Mcloughlin E, Smith D, Criddle D, Sutton R: Mechanisms of acinar cell injury in acute pancreatitis. Scand J Surg 2005, 94:89-96

2. Saluja AK, Donovan EA, Yamanaka K, Yamaguchi Y, Hofbauer B, Steer ML: Cerulein-induced in vitro activation of trypsinogen in rat pancreatic acini is mediated by cathepsin B. Gastroenterology 1997 , 113:304-310

3. Norman J: The role of cytokines in the pathogenesis of acute pancreatitis. Am J Surg 1998, 175:76-83

4. Bhatia M, Brady M, Shokuhi S, Christmas S, Neoptolemos JP, Slavin $\mathrm{J}$ : Inflammatory mediators in acute pancreatitis. J Pathol 2000, 190: $117-125$

5. Bhatia M, Wong FL, Cao Y, Lau HY, Huang J, Puneet P, Chevali L: Pathophysiology of acute pancreatitis. Pancreatology 2005, 5:132144

6. Pooran N, Indaram A, Singh P, Bank S: Cytokines (IL-6. IL-8, TNF): early and reliable predictors of severe acute pancreatitis. J Clin Gastroenterol 2003, 37:263-266

7. Mayer J, Rau B, Gansauge F, Beger HG: Inflammatory mediators in human acute pancreatitis: clinical and pathophysiological implications. Gut 2000, 47:546-552

8. Dugernier TL, Laterre PF, Wittebole X, Roeseler J, Latinne D, Reynaert MS, Pugin J: Compartmentalization of the inflammatory response during acute pancreatitis: correlation with local and systemic complications. Am J Respir Crit Care Med 2003, 168:148-157

9. O'Shea JJ, Gadina M, Schreiber RD: Cytokine signaling in 2002: new surprises in the Jak/Stat pathway. Cell 2002, 109(Suppl):S121-S131

10. Akira S, Nishio Y, Inoue M, Wang XJ, Wei S, Matsusaka T, Yoshida K, Sudo T, Naruto M, Kishimoto T: Molecular cloning of APRF, a novel IFN-stimulated gene factor 3 p91-related transcription factor involved in the gp130-mediated signaling pathway. Cell 1994, 77:63-71

11. Zhong Z, Wen Z, Darnell JE: Stat3: a STAT family member activated by tyrosine phosphorylation in response to epidermal growth factor and interleukin-6. Science 1994, 264:95-98

12. Kobierski LA, Srivastava S, Borsook D: Systemic lipopolysaccharide and interleukin-1beta activate the interleukin 6: STAT intracellular 
signaling pathway in neurons of mouse trigeminal ganglion. Neurosci Lett 2000, 281:61-64

13. Obana M, Maeda M, Takeda K, Hayama A, Mohri T, Yamashita T, Nakaoka Y, Komuro I, Matsumiya G, Azuma J, Fujio Y: Therapeutic activation of signal transducer and activator of transcription 3 by interleukin-11 ameliorates cardiac fibrosis after myocardial infarction. Circulation 2010, 121:684-691

14. Li W, Liang X, Kellendonk C, Poli V, Taub R: STAT3 contributes to the mitogenic response of hepatocytes during liver regeneration. $J$ Bio Chem 2002, 277:28411-28417

15. Sakamori R, Takehara T, Ohnishi C, Tatsumi T, Ohkawa K, Takeda K, Akira S, Hayashi N: Signal transducer and activator of transcription 3 signaling within hepatocytes attenuates systemic inflammatory response and lethality in septic mice. Hepatology 2007, 46:1564-1573

16. Robinson K, Vona-Davis L, Riggs D, Jackson B, McFadden D: Peptide $Y Y$ attenuates STAT1 and STAT3 activation induced by TNFalpha in acinar cell line AR42J. J Am Coll Surg 2006, 202:788-796

17. Vona-Davis LC, Frankenberry KA, Waheed U, Peterson E, McFadden DW: Expression of STAT3 and SOCS3 in pancreatic acinar cells. J Surg Res 2005, 127:14-120

18. Yubero S, Ramudo L, Manso MA, De Dios I: The role of redox status on chemokine expression in acute pancreatitis. Biochim Biophys Acta 2009, 1792:148-154

19. Takeda K, Noguchi K, Shi W, Tanaka T, Matsumoto M, Yoshida N, Kishimoto T, Akira S: Targeted disruption of the mouse Stat3 gene leads to early embryonic lethality. Proc Natl Acad Sci U S A 1997 , 94:3801-3804

20. Takeda K, Kaisho T, Yoshida N, Takeda J, Kishimoto T, Akira S: Stat3 activation is responsible for IL-6-dependent $T$ cell proliferation through preventing apoptosis: generation and characterization of $T$ cell-specific Stat3-deficient mice. J Immunol 1998, 161:4652-4660

21. Shigekawa M, Takehara T, Kodama T, Hikita H, Shimizu S, Li W, Miyagi T, Hosui A, Tatsumi T, Ishida H, Kanto T, Hiramatsu N, Hayash $\mathrm{N}$ : Involvement of STAT3-regulated hepatic soluble factors in attenuation of stellate cell activity and liver fibrogenesis in mice. Biochem Biophys Res Commun 2011, 406:614-620

22. Uemura A, Takehara T, Miyagi T, Suzuki T, Tatsumi T, Ohkawa K Kanto T, Hiramatsu N, Hayashi N: Natural killer cell is a major producer of interferon gamma that is critical for the IL-12-induced antitumor effect in mice. Cancer Immunol Immunother 2010, 59:453-463

23. Chen C, Fang R, Davis C, Maravelias C, Sibley E: Pdx1 inactivation restricted to the intestinal epithelium in mice alters duodenal gene expression in enterocytes and enteroendocrine cells. Am J Physiol Gastrointest Liver Physiol 2009, 297:G1126-G1137

24. Jensen JN, Cameron E, Garay MV, Starkey TW, Gianani R, Jensen J: Recapitulation of elements of embryonic development in adult mouse pancreatic regeneration. Gastroenterology 2005, 128:728-741

25. Keim V, Rohr G, Stöckert HG, Haberich FJ: An additional secretory protein in the rat pancreas. Digestion 1984, 29:242-249

26. Iovanna JL, Keim V, Nordback I, Montalto G, Camarena J, Letoublon C, Lévy $P$, Berthézène $P$, Dagorn JC, Multicentric Study Group on Acute Pancreatitis: Serum levels of pancreatitis-associated protein as indicators of the course of acute pancreatitis. Gastroenterology 1994 106:728-734

27. Folch-Puy E, Granell S, Dagorn JC, Iovanna JL, Closa D: Pancreatitisassociated protein I suppresses NF-kappa B activation through a JAK/STAT-mediated mechanism in epithelial cells. J Immunol 2006, 176:3774-3779

28. Dusetti NJ, Ortiz EM, Mallo GV, Dagorn JC, Iovanna JL: Pancreatitisassociated protein I (PAP I), an acute phase protein induced by cytokines. Identification of two functional interleukin-6 response elements in the rat PAP I promoter region J Biol Chem 1995, 270:2241722421

29. Miyatsuka T, Kaneto H, Shiraiwa T, Matsuoka TA, Yamamoto K, Kato K, Nakamura Y, Akira S, Takeda K, Kajimoto Y, Yamasaki Y, Sandgren EP, Kawaguchi Y, Wright CV, Fujitani Y: Persistent expression of PDX-1 in the pancreas causes acinar-to-ductal metaplasia through Stat3 activation. Genes Dev 2006, 20:1435-1440

30. Scholz A, Heinze S, Detjen KM, Peters M, Welzel M, Hauff P, Schirne M, Wiedenmann B, Rosewicz S: Activated signal transducer and activator of transcription 3 (STAT3) supports the malignant phenotype of human pancreatic cancer. Gastroenterology 2003, 125:891-905
31. Greten FR, Weber CK, Greten TF, Schneider G, Wagner M, Adler G, Schmid RM: Stat3 and NF-kappaB activation prevents apoptosis in pancreatic carcinogenesis. Gastroenterology 2002, 123:2052-2063

32. Aggarwal BB, Kunnumakkara AB, Harikumar KB, Gupta SR, Tharakan ST, Koca C, Dey S, Sung B: Signal transducer and activator of transcription-3, inflammation, and cancer: how intimate is the relationship? Ann N Y Acad Sci 2009, 1171:59-76

33. Moniaux N, Song H, Darnaud M, Garbin K, Gigou M, Mitchell C, Samuel D, Jamot L, Amouyal P, Amouyal G, Bréchot C, Faivre J: Human hepatocarcinoma-intestine-pancreas/pancreatitis-associated protein cures fas-induced acute liver failure in mice by attenuating free-radical damage in injured livers. Hepatology 2011, 53:618-627

34. Gironella M, lovanna JL, Sans M, Gil F, Peñalva M, Closa D, Miquel R, Piqué JM, Panés J: Anti-inflammatory effects of pancreatitis associated protein in inflammatory bowel disease. Gut 2005, 54:1244-1253

35. Moucadel V, Soubeyran P, Vasseur S, Dusetti NJ, Dagorn JC, Iovanna JL: Cdx1 promotes cellular growth of epithelial intestinal cells through induction of the secretory protein PAP I. Eur J Cell Biol 2001 80:156-163

36. Simon MT, Pauloin A, Normand G, Lieu HT, Mouly H, Pivert G, Carnot F, Tralhao JG, Brechot C, Christa L: HIP/PAP stimulates liver regeneration after partial hepatectomy and combines mitogenic and antiapoptotic functions through the PKA signaling pathway. FASEB J 2003, 17:1441-1450

37. Dieckgraefe BK, Stenson WF, Korzenik JR, Swanson PE, Harrington CA: Analysis of mucosal gene expression in inflammatory bowel disease by parallel oligonucleotide arrays. Physiol Genomics 2000, 4:1-11

38. Averill S, Davis DR, Shortland PJ, Priestley JV, Hunt SP: Dynamic pattern of reg-2 expression in rat sensory neurons after peripheral nerve injury. J Neurosci 2002, 22:7493-7501

39. Orelle B, Keim V, Masciotra L, Dagorn JC, Iovanna JL: Human pancreatitis-associated protein. Messenger RNA cloning and expression in pancreatic diseases. J Clin Invest 1992, 90:2284-2291

40. McKie AT, Simpson RJ, Ghosh S, Peters TJ, Farzaneh F: Regulation of pancreatitis-associated protein (HIP/PAP) mRNA levels in mouse pancreas and small intestine. Clin Sci (Lond) 1996, 91:213-218

41. Vaccaro MI, Calvo EL, Suburo AM, Sordelli DO, Lanosa G, Iovanna JL: Lipopolysaccharide directly affects pancreatic acinar cells: implications on acute pancreatitis pathophysiology. Dig Dis Sci 2000, 45:915-926

42. van der Pijl JW, Boonstra JG, Barthellemy S, Smets YF, Hermans J, Bruijn JA, de Fijter JW, Daha MR, Dagorn JC: Pancreatitis-associated protein: a putative marker for pancreas graft rejection. Transplantation 1997, 63:995-1003

43. Vasseur S, Folch-Puy E, Hlouschek V, Garcia S, Fiedler F, Lerch MM, Dagorn JC, Closa D, lovanna JL: p8 improves pancreatic response to acute pancreatitis by enhancing the expression of the anti-inflammatory protein pancreatitis-associated protein I. J Biol Chem 2004, 279:7199-7207

44. Gironella M, Folch-Puy E, LeGoffic A, Garcia S, Christa L, Smith A, Tebar L, Hunt SP, Bayne R, Smith AJ, Dagorn JC, Closa D, Iovanna JL: Experimental acute pancreatitis in PAP/HIP knock-out mice. Gut 2007, 56:1091-1097

45. Algül H, Treiber M, Lesina M, Nakhai H, Saur D, Geisler F, Pfeifer A, Paxian S, Schmid RM: Pancreas-specific RelA/p65 truncation increases susceptibility of acini to inflammation-associated cell death following cerulein pancreatitis. J Clin Invest 2007, 117:1490-1501

46. Ortiz EM, Dusetti NJ, Vasseur S, Malka D, Bödeker H, Dagorn JC, lovanna JL: The pancreatitis-associated protein is induced by free radicals in AR4-2 $\mathrm{J}$ cells and confers cell resistance to apoptosis. Gastroenterology 1998, 114:808-816

47. Malka D, Vasseur S, Bödeker H, Ortiz EM, Dusetti NJ, Verrando P, Dagorn JC, Iovanna JL: Tumor necrosis factor alpha triggers antiapoptotic mechanisms in rat pancreatic cells through pancreatitis-associated protein I activation. Gastroenterology 2000, 119:816-828

48. Yu H, Pardoll D, Jove R: STATs in cancer inflammation and immunity: a leading role for STAT3. Nat Rev Cancer 2009, 9:798-809

49. Epling-Burnette PK, Liu JH, Catlett-Falcone R, Turkson J, Oshiro M, Kothapalli R, Li Y, Wang JM, Yang-Yen HF, Karras J, Jove R, Loughran TP: Inhibition of STAT3 signaling leads to apoptosis of leukemic large granular lymphocytes and decreased $\mathrm{Mcl}-1$ expression. J Clin Invest 2001, 107:351-362 